\title{
LEGAL EDUCATION, ETHICS AND ACCESS TO JUSTICE: FORGING WARRIORS FOR JUSTICE IN A NEO-LIBERAL WORLD
}

Donald Nicolson ${ }^{\mathrm{i}}$

\section{Introduction}

One issue which has yet to receive any attention in the debate over the future shape of UK legal education post-LETR ${ }^{\mathrm{ii}}$ is the place of access to justice (ATJ) in the curriculum. Currently, ATJ is one of eleven specified elements of one of the six areas of required knowledge for Scottish qualifying law degrees (Law Society of Scotland, 2010), whereas the English and Welsh Joint Statement on the Academic Stage of Training (Law Society and the General Council of the Bar, 1995) ignores the topic altogether. Short of a survey, it is difficult to ascertain how many law schools buck the traditional focus on covering the professionally required core in great detail and on substantive law options, but it is instructive that in the last survey of UK law schools (Harris and Beinart, 2004), only 20\% taught legal system or skills courses, which along with from brief, often unassessed, introductions to law constitute the traditional home for ATJ. No doubt, some academics might discuss ATJ in classes dealing with legal process, sociology of the law, etc, but clearly the topic has a precarious and peripheral place in the curriculum.

This article argues that ATJ should be a central concern for both legal education and legal practitioners, and explores the potential for inculcating such a concern in law graduates through both traditional courses and clinical experience. Indeed, it argues that this potential is enhanced by the very same neo-liberal forces that make the issue of ATJ so urgent in UK society today and which seem to militate against an education which prioritises the sort of critical, contextual, and socio-legal approach which one might associate with ATJ teaching. To understand the paradox, it is necessary to start with these neo-liberal forces. 


\section{Access to justice and legal education in a neo-liberal world}

In its contemporary (but not original) usage (Boas and Gans-Morse, 2009), neo-liberalism refers to an extreme form of laissez faire economic theory associated with Hayek and Friedman (see eg Clarke, 2004, Harvey, 2005, Thornton 2010, ch. 1). It champions economic liberalisation, privatisation, free trade and deregulated markets, and seeks to reduce government spending as far as possible. Neo-liberalists believe that leaving matters to private enterprise is far more efficient than collective action, and consequently seek to replace the state with private enterprise, and notions of social justice and the public good with profitmaking and self-interest. As Sarat and Scheingold put it: '[w]hereas once laissez-faire meant keeping the state out of the market, today neoliberalism means bringing the market into the state' (Sarat \& Scheingold 2001, 7). In practice, virtually no sphere of UK society has been spared the neo-liberal turn - certainly not ATJ and higher education. Indeed, it has been said that neo-liberalism 'has become incorporated into the common-sense way many of us interpret, live, and understand the world.' (Harvey, 2005, p.3), producing an intensively individualistic subject - homo eeconomicus -who sees the world in terms of rational selfinterest (see eg Read, 2009)

The impact of neo-liberalism on legal education has been most comprehensively documented by Thornton (eg 2010, 2012; see also eg Webb, 1999; Goldsmith, 2002; Bradney, 2003; Boon \& Webb, 2010; Goldsmith \& Bamford, 2010). Higher education in general has seen state investment plummet while student numbers shoot up, leading to increased teaching and administrative loads, and increased pressure to produce more research and more funded research. Moreover, especially after fees were introduced in England and Wales, a university education has been transformed from a public good into a commodity 
marketed to student 'consumers' who in classical homo oeconomicus terms seem more interested in gaining credentials to compete on the labour market than intellectual and personal growth.

This is a familiar story for all academics, but law schools face additional pressures. One source is the legal profession, itself facing the chill winds of neo-liberalism in the form of cutbacks to legal aid and competition from outside providers following deregulation of legal services and the shrinking of traditional monopolies. Along with globalisation, this has lead to law firms becoming bigger, and more profit-oriented and business-minded (see eg Lee 1992; Sommerlad 1995; Francis 2005). Consequently, they seek graduates with the necessary skills and knowledge to be practice-ready profit-makers. In fact, the demands of all law employers for skills training and from the powerful large law firms for a focus on legal subjects relevant to commercial practice are echoed within the academy. As consumers of education services burdened with debt, students demand that their education makes them attractive to those employers who can ensure that they can repay their debts as quickly as possible, thus increasing the pull of commercial law practice. The resultant enhancement of student credentialism means that many law students are only interested in taking the core doctrinal subjects and optional subjects perceived to be attractive to prospective employers, such as those involving skills training or which have the same property and profits orientation as the core. This vocational focus is echoed by university management which has an interest in maximising student employment in order to attract new customers and appease the god of university league tables (see Hazelkorn, 2008 generally and Sauder \& Espeland, 2009 in relation to (US) law schools).

These pressures are not, however, uniformly felt. Elite universities are better placed than others to resist demands for greater vocationalism because students are arguably more interested in the cachet of their 'brand name' than subjects taught and many employers seem 
more interested in 'input' as represented by the new proxies for social class - school attended, incoming students's school results and most social background-crucially the status of university attended and $\theta_{-}$and onnly in 'output' as represented by a 'decent degree' (Sommerladd. 2007; Boon and White, 2010, p. 213, 220; Ashley and Empson 2013). It is thus unsurprising that the 'new' universities have been more willing to produce vocationallyoriented curricula (Boon \& Webb, 2010, p.82).

Nor has the neo-liberal project of constructing a hegemonic homo œconomicus $\underline{\text { subjectivity been entirely successful. Some students still enter law school with altruistic }}$ rather than self-interested reasons for studying law (Nicolson, 2013, pp. 41-43).

Nevertheless, all law schools have undoubtedly changed from the days in which they academics could teach according to their academic and political beliefs, albeit within the confines of qualifying degree requirements. Thornton is most exercised by the strangling of more theoretical, critical and social-legal approaches to law only shortly after their birth in the 1970s. This reversal of such a 'socially liberal' legal education has, she argues, been accelerated by a number of cost-cutting measures like the reversion from small-group teaching to lectures which, like virtual and intensive learning, involve a 'one-way flow' of 'frozen knowledge' concentrating on doctrine, and from extended essays to unreflective forms of assessment like tests and hypothetical problems. However, while Thornton makes an eloquent call for law schools 'to resist the temptation to produce narrow technocrats' (2012, 276), she offers little by way of concrete strategy for doing so.

Apart from Bradney's suggestion that the 'ivory tower is better defended from behind a moat with a raised drawbridge' (1995; see also Bradney, 2003) a similar lack of strategy is displayed by those who champion the more traditional conception of a liberal education in which knowledge is regarded as an end in itself, students are educated as persons and not workers, and universities prepare graduates for citizenship as much as a career (eg 
Brownsword, 1999; Guth \& Ashford, 2014). Bradney argues that a liberal legal education involves introducing law students to 'a variety of conversations which are going on within law' (2003, p. 87) and to the all-pervasive nature of values in law, but without seeking to indoctrinate particular views. Bradney accepts that wholly technical matters can and indeed should be taught; otherwise, the discussion of underlying legal principles and values will be shallow. However, he argues that 'employers cannot expect university law schools to make sure that they get only those graduates who they find to be suitable employees' (2003, p. 172), not least because there is no common set of skills and knowledge in the modern-day highly fragmented legal profession and because so many graduates do not enter practice.

By contrast, while also decrying the neo-liberal turn in legal education, Boon and Webb (2010) warn that law schools ignore professional demands for a greater vocational focus at the risk of the undergraduate law degree being replaced as the primary route to professional qualification by alternatives such as private legal education In such circumstances, the scope for more critical, theoretical and contextual approaches to law would dwindle to near vanishing point. Similarly, Goldsmith and Bamford (2010) and Boon and White (2010) argue that students have an equally legitimate claim to be stakeholders in legal education as without them law schools would not exist. According to Goldsmith and Bamford, '[w]ho we are as legal academics cannot be separated wholly from who our students are' (2010, p. 179) and thus law schools cannot ignore their demands for greater engagement with legal practice. However, they do not see such engagement in purely vocational or technocratic terms. Instead, it may provide opportunities for connecting the 'aspirations of law students with professional ideals (justice, service, fairness) and the goals of a university-based education' (2010, p. 163; see also Goldsmith 1999, 2002; Boon 1998, 166). Moreover, according to Goldsmith (2002) and many others (see references cited by Nicolson 2008, p. 165n.120), student involvement in live-client clinics provides the best 
means to this end, while also ensuring an appreciation of law, justice and legal ethics that cannot be gleaned from any amount of standard teaching and learning.

In the rest of the article, I apply these insights to the more specific goal of giving greater prominence to ATJ in legal education and to inculcating in students a commitment to the ideal of community service, albeit drawing upon a law clinical model which differs to that envisaged by Goldsmith and which, I will argue. provides a site for launching a counterhegemonic challenge to the neo-liberal vision of legal practice. First, however, the case for law schools and law graduates to take ATJ more seriously needs to be made.

\section{Taking access to justice seriously}

Here, at least four reasons can be offered. The first and most obvious is that justice is a central concern of a liberal legal education in its traditional or more critical incarnations. And, if one is interested in justice, then the fact that so many people are absolutely excluded from obstaining legal services or are handicapped by inferior legal services or selfrepresentation in obtaining whatever substantive justice law offers needs to be highlighted. Indeed some argue that access to a lawyer is a human right (Luban, 2014) or at least an $\underline{\text { essential prerequisite for human dignity, the rule of law and law's legitimacy (Luban, }}$

\section{$\underline{1988, \text { ch. } 11 ; 2005) \text { and possibly even democracy (Luban, 1985) }}$}

Secondly, even if one's aim is simply to describe law in realistic (as opposed to blackletter) terms, it also seems necessary to pay due attention to the fact that so many people are unable to vindicate their rights or defend themselves against legal detriments. For instance, to teach employment law without mentioning the difficulties of obtaining legal aid or the impact of recent Employment Tribunal fees would be grossly misleading. Moreover, attention to ATJ helps illuminate the contours of substantive law. For example, areas of law dominated 
by case law will tend to reflect the interests of those who can access the courts and effectively vindicate their interests, rather than of those who cannot litigate or litigate effectively.

Thirdly, I would argue that ATJ is highly relevant to legal education if, as is becoming increasingly the case (Webb et al, 2013, paras 4.65-4.67), one regards legal ethics as a core element of undergraduate legal education. This is because, by analogy with Rawls's argument that '[j] ustice is the first virtue of social institutions (Rawls, 1999, p. 3), it can be argued that the first virtue of the ethical lawyer is to ensure ATJ. Traditionally, legal ethics discourse focuses on issues of the morality of representation, both from the internal dimension of how lawyers should treat clients - do they respect their autonomy, protect their secrets and zealously pursue their interests? - and the external dimension of how they should treat others affected by client representation - do they unjustifiably harm the interest of others, the administration of justice or the public interest more broadly? Such a focus, however, only goes so far in aligning lawyers' ethics with their calling to seek justice, which after all is the legitimatory justification for lawyer's professional status (Nicolson 2013).

For one thing, the goal of making practitioners aware of problems with neutral partisanship, confidentiality, conflicts and client autonomy is undermined where their scope for moral manoeuvre is highly constrained by financial considerations which cast morality as an unaffordable luxury or where responsibility for ethics tends to fall into the cracks because of the increasing specialisation of legal work or completely out of sight because of its increasing routinisation (see Nicolson and Webb 1999, ch. 3). This does not mean that law schools should not seek to ensure that law graduates enter practice with a desire to uphold ethical values where they can, if not fight for greater moral manoeuvre to do the right thing. Moreover, if ATJ problems are made more central to legal ethics teaching, lawyers might be more inclined to give them due regard in deciding on the morality of actions on behalf of clients (cf Nicolson and Webb, 1999, chs 8-10). However, it seems obvious that ethically 
aware lawyers either devoting their career to those most in need of legal services or doing so pro bono is an improvement on only providing ethically aware services to the shrinking group of those who can afford to pay or obtain legal aid.

Indeed, as I have recently argued (Nicolson 2013), notions of reciprocity or gratitude towards the community which through its taxes pays for school education and, still in Scotland, for much of the cost of legal education suggest that lawyers have a moral obligation to contribute in some way to enhancing ATJ. Public investment in their education enables law students to enjoy substantial financial rewards. However, only those fortunate enough to afford lawyers or qualify for legal aid benefit from this investment. Moreover, a major obstacle to ATJ is the high fees charged by lawyers. Consequently, it can be argued that these lawyers have a moral duty to take some remedial action to repay those who helped put them in their privileged position, but do not benefit from this investment. Two further arguments support a moral obligation on lawyers to enhance ATJ. One is that their earnings are partly albeit decreasingly - protected by state limitations on who can practice law and access legal processes. Secondly, many ATJ problems, especially of a relative nature, stem from often unnecessary and difficult to understand legal complexities created by lawyers serving their clients (and indirectly themselves by making legal assistance more necessary). Here, lawyers can be said to have a moral obligation to help remedy the resultant ATJ obstacles.

Indeed, and as a fourth reason for making ATJ more central to legal education, given that their livelihood is partly dependent on educating those who make a good living from legal practice, it is arguable that academics have similar obligation to enhance ATJ through consistently emphasising ATJ in their teaching and/or researching issues of ATJ but, preferably, because of the positive example it sets to students, through community legal work (Rhode, 2004, p. 157; Nicolson 2012), as was relatively common in the past (Partington 1988, p. 381). 


\section{Locating access to justice in the curriculum}

If these arguments about the importance of ATJ in legal education are persuasive, they raise the question of where to locate ATJ in the curriculum and how we might inspire students to take ATJ seriously. I will concentrate largely on the latter issue since my views on the former largely track those I have previously expressed on teaching ethics at the academic stage of legal education, namely that ethics should be taught both pervasively and in compulsory stand-alone classes, and then backed up through live-client clinical experience (Nicolson 2008). While pervasive teaching will expose students to the ubiquitous nature of ATJ obstacles and how the law taught in the rest of the curriculum actually operates in practice, unless taugth voluntarily, academics are likely to surreptitiously (or even not so surreptitiously) undermine the intended message and hence necessitate a stand-alone class.

However, unlike legal ethics, this need not be a full class. Instead, there are many potential homes for discussing ATJ. In addition to its common location in Introduction to Law, Legal System, and Legal Process classes, it could be taught alongside legal ethics or in Sociology of Law/Socio-Legal Studies classes. In addition to providing a comprehensive picture of the ATJ landscape, it is important that such classes are given a coherence, for instance by linking ATJ to related issues like the role of lawyers, legal ethics and legal professionalism, rather than comprising a ragtag of issues which come across as 'stuff not covered elsewhere in the important part of the curriculum'.

The more challenging issue involves the timing of stand-alone ATJ teaching. On the one hand, an early introduction to ATJ problems allows them to be referred to pervasively. It might also help prevent an indelibly rosy picture of law's justice developing and encourage a more critical approach generally. On the other hand, if ATJ is not taught pervasively there is 
a case for locating it towards the end of the degree. This will allow reference to examples from other classes of how ATJ problems undermine law and justice. Moreover, it is arguable that will have more impact than if students are initially told: 'you are about to study areas of law which may provide valuable legal rights but be aware that many people may not be able to access these rights', and then left to work out when and to what extent this applies. The impact of such a message is also likely to be undermined by the fact that incoming students expect to learn criminal law, contract, property law, etc and may either pay less attention to non-substantive subjects or positively resent being distracted from 'real' law subjects.

\section{Access to justice and active learning}

While the question of the most effective location for ATJ teaching is a matter of speculation, by contrast, and by analogy with the growing consensus around ethics teaching (see Nicolson 2008, p. 165), few are likely to doubt that the most promising means of encouraging students to take ATJ seriously is through exposure to those most in need of legal services via university law clinics or placements (or 'externships') in external legal service agencies. Lectures and even the most imaginative small group exercises, such as requiring students to decided how to allocate scarce legal aid resources amongst a list of needy applicants (victims of domestic abuse, asylum seekers, sacked single parents, etc), are never going to compete with the well-recognised advantages of combining exposure to 'theoretical' knowledge with actual experience (see eg Bloch, 1982; Brayne et al, 1998). Thus, learning in adults is more effective if it draws upon actual experiences, and knowledge can be applied immediately in the fulfilment of expected future roles rather than stored for future use. Such learning also goes deeper - both in the sense of knowledge being better understood and more readily accessible - where learners are not treated as passive receptacles of abstract information to be 
memorised and regurgitated, but required to obtain and transform knowledge through selfdiscovery and reflection.

If evidence of these advantages of experiential (or active) learning in relation to ATJ is required, it can be seen in the spontaneous comments in both oral examinations and reflective diaries ${ }^{\mathrm{iii}}$ by University of Strathclyde Law Clinic (USLC) student volunteers who either opt to take Ethics and Justice, a class exploring issues of legal ethics and ATJ in the context of their clinic cases, or are required to as part of the Clinical LLB which integrates clinic training and case experience into the standard LLB (see Nicolson, 2013, pp. 51-55). Thus, as one student responded in an oral examination when questioned about what she had most learnt from four years in the clinic: 'Theoretically in Legal Process [a first year class] they tell you that there is an unmet legal need, but that is one of those things that are intangible unless you really experience it.' In answer to the same question, another said: ...the system is mince. You don't realise how bad it is in the abstract, reading tables about legal aid. And then you realise that it is endemic and desperate, and it's only getting worse. The amazing thing is that it is so pervasive that it has come up in every essay I have written this year.

Similar views were expressed in a diary entry: 'Before I joined the Clinic I had a strong, but quite vague, feeling that there was injustice in the legal system, but now having been involved with clients and cases I feel that I have a much more focused idea of what the problems are and where the injustice comes from, especially the availability (or lack thereof) of Legal Aid funding and the way the Tribunal system runs compared to how it was supposedly designed to ....'

However, it is one thing for students to appreciate the extent of ATJ problems and quite another for them to take remedial action once they graduate. Adapting Rest's now familiar model of the four psychological conditions required for moral behaviour (eg Rest, 
1994), one might be confident that clinic students will develop the necessary sensitivity to problems of ATJ. However, they still need the necessary judgment to know how best to respond and, given that empirical research repeatedly shows that ethical knowledge is only weakly connected to ethical behaviour (eg Rest, 1994, 21-2), the commitment to care about doing the right thing and the courage to resist competing pressures and temptations. Fostering and guiding the development of these three components is likely to prove much more challenging.

To guide judgment, students must obviously be exposed to arguments about lawyers' moral responsibilities in relation to ATJ and the various ways in which they can be met. These range from devoting one's career to helping those most in need, such as by working in legal aid practices, advice agencies or relevant law reform organisations, to engaging in various forms of pro bono work (most obviously giving advice and/or representation, but also training or otherwise supporting others involved in ATJ) or substantially reducing fees to indigent clients ('low bono'), and finally to financially supporting those who work at the ATJ coalface. $^{\text {iv }}$

Persuading students of their obligations to enhance ATJ is unlikely to be easy. Those who regard neo-liberal ideology as a matter of common sense are likely to respond that individual lawyers are not responsible for imperfections in the legal services market, which in the long run is the most effective means of ensuring ATJ. More left-earning students might insist that the state should guarantee ATJ and that engaging in or financially supporting pro bono work or other organisations providing free legal assistance allows it to escape its responsibilities. But even if students resist the siren calls of neo-liberalism or the naïve optimism in its imminent demise, their commitment to a career enhancing ATJ will be tested by factors which flow from or are exacerbated by the neo-liberal impact on edcuatrion and legal practice such as the desire to repay debts and more generally to benefit from the 
monetary investment in their education, whereas their commitment to engage in pro bono or financially support ATJ will be tested by the long hours of much legal work, and the time and financial pressures involved in trying to balance work and family life (Rhode, 2004, pp.166-

\section{3; Sommerlad, 2007, p.202).}

Nevertheless, both theory and growing evidence from USLC student diaries suggests that clinical experience can prompt students to commit to enhancing ATJ once they qualify. Thus development psychologists, especially those influenced by the Aristotelian focus on character development (see Nicolson 2008, pp. 156-9, 165), point to at least three set of factors associated with the repeated immersion in morally charged life-experiences which help develop and sustain such commitment. One is that the exposure to flesh and blood people facing ATJ obstacles may evoke the emotions empathy or sympathy, which are so crucial to the development of a sense of compassion and personal moral responsibility (eg

\section{Hoffman, 2001).}

The client came to the clinic really as a last chance saloon after being through solicitors working pro-bono and also the $\mathrm{CAB}$. When I found out that the client had already been through so much it hit me personally and I felt sad for the client knowing that she had been through so many different loops trying to seek justice problems.

The more the client talked about his last few months at his job, and how much he'd enjoyed his work before that, the worse I felt for him. ... I found myself feeling really terrible for him, ...

But it was not just feelings of empathy and sympathy which were evoked by cases, as the following shows:

The thing that makes me angry in cases like these is the fact that companies like these must rely on people not seeking legal advice and instead just accepting that they signed 
a contract, and therefore have no remedy if they wanted a refund. ..... In a hard economic climate, people seem more willing to walk over others to protect themselves, and I'm glad that the Law Clinic gives me a chance to stick up for people who may otherwise be trampled.

A second important influence on moral development is the example set by role models. Here, lawyers who support clinic activities were frequently mentioned. Thus one student commented that ' $[\mathrm{i}] \mathrm{t}$ is very heartening to see how many people are prepared to give up their time and resources to come in and do training events for students.' This sentiment was echoed by another's comments on the lawyers who volunteer for the USLC's evening advice sessions:

I have been heartened by the strength of their commitment to the project and to the pro bono cause in general. The practitioners are very busy individuals who are giving of their time at the end of what I'm sure is a long and often stressful day and this gives me a degree of comfort about the profession I am planning to enter.

Even clearer in evincing a commitment to ATJ after graduation were two students who were inspired by a practitioner teaching Ethics and Justice. Thus, her work as a legal aid lawyer and founder of an environmental law centre showed Isla that she "can work in private practice and still achieve her ultimate aim of helping others', whereas Seamus declared that by 'putting something back into the community' through her pro bono assistance of his client she had acted as 'a positive role model' and been 'inspirational to me for my own career'.

Finally, a third crucial influence on moral development are feelings of satisfaction or regret evoked by events. For example, informing a client that her employment case had been unsuccessful was for one student 'one of the hardest things I've done in the law clinic from an emotional standpoint. This was partly due to the fact that mistakes were made on this case and I had a strong feeling of having let the client down.' Conceivably this experience is likely 
to make her more inclined to go the extra mile for clients in the future. Far more frequently, students highlighted their satisfaction at helping clients, with some indicating that this has made them think differently about their future careers. Thus Isla's satisfaction at helping a client who had been turned down by eight law firms, prompted her to state:

I didn't start my law degree to 'make a difference'. My goal was simply to earn enough money so I can afford some of life's luxuries and have no financial troubles. However, having seen the positive effect my time and effort has had on clients of the clinic has changed my perspective and now, my ultimate goal is to find a job that provides both financial security and a chance to help communities or less fortunate individuals.'-

In addition to these specific influences on moral development, students frequently cited their clinic experience more generally and the shared ethos of USLC students as influencing their attitudes to ATJ, as the following show:

When I started on the path to a law degree... I thought I believed in access to justice for all; that judicial justice shouldn't just be the preserve of those with the money to pay for it. Having spent more time, and become involved in the work of the Law Clinic, I now know that I believe in access to justice, not just as a theory, but in practice.

The most remarkable thing that has struck me is that my drive for access to justice has actually increased in my time in the clinic whereas I thought there was a risk that this spark would disappear once I got into the swing of things. This I believe is down to the attitude of the whole Clinic which keeps advisors motivated to strive towards assisting many people in the best way possible.

In some cases, appreciation of ATJ problems led to the assertion of an intention to play a role in redressing them once in practice, as these entries illustrate: 
Since losing his appeal, everywhere he has turned, the door has been closed. CAB refused to assist; firms of solicitors were also ignorant of the law, and also declined. Such ignorance deprives those most in need of access to justice, and a fair outcome. ... Surely it is essential that justice is accessible to all, regardless of who they are? That is the overriding reason why I want to work in the legal profession.

Once I become a practising solicitor, I hope to continue pro bono work as helping people without expectation does make you feel good about yourself and increasing access to justice will provide more people with the legal expertise required to resolve their dispute.

Even more dramatically, Calum stated, '[b]efore my experience in the Clinic, I had imagined a career in a large law firm and hadn't really considered the larger ideal of social justice.... Now I find it impossible not to.'

But these were not empty words. Calum now works for a law centre. More generally, many of those students who diaries have been analysed and are now in practice have, like Isla acted upon their stated intention to pursue a career which serves social justice or like Seamus fulfilled their stated commitment to engage in pro bono assistance, as well as donating to the USLC. Indeed, so many USLC alumni have returned to staff evening advice sessions that it has doubled the number of clients advised each year.

\section{Access to justice and clinic models}

However, while these anecdotal observations about the link between clinical experience and post-graduation behaviour are echoed by many others (see references cited in Nicolson, 2008, p.165n.124), Sandefur and Selbin (2009) found that, when (recollected) attitudes students had when entering US law schools were controlled for, there was no evidence of clinical 
experience developing, as opposed to sustaining, a pre-existing commitment to engage in pro bono or practise law for the benefit of others (see also Rhode (2004, ch. 7 and Granfield, 2007 on more wide ranging pro bono programmes which also include externships, legal research projects, but $\mathrm{cf}$ the more positive findings of Schmedemann, 2009 including in relation to clinic involvement). Of course, this is no mean achievement itself given the generally negative impact US legal education has on students' altruistic motivations for practising law (summarised in Granfield and Veliz 2009, pp. 53-4) and the already noted dominance of the values of homo æeconomicus in contemporary neo-liberal world. However, in addition to possible differences in pre-existing altruistic attitudes between US students and those entering the USLC, ${ }^{v}$ and in the impact of their legal education on such attitudes (Nicolson) differences in clinic ${ }^{\mathrm{vi}}$ orientation and resultant student experiences might also be important.

The in-house clinic model adopted in most law schools is one which, as Sanderfur and Selbin's reference to 'clinical training' suggests (2009, passim), prioritises teaching legal skills, how law operates and sometime also legal ethics. Usually clinic involvement is limited to one or at most two semesters (though in the US students may take more than one clinical class), and the focus on student learning dictates low staff-student ratios and low caseloads. In too quickly dismissing clinics as a beachhead for resisting the neo-liberal turn Thornton (2010, pp. 83-4) has in mind such 'educationally-oriented' (EO) clinics, which she correctly sees as too expensive to involve many students being exposed to issues of social justice.

By contrast, as I have argued elsewhere (Nicolson 2006 and 2015), social-justice oriented (SJO) clinics, particularly if wholly or largely extra-curricular, have a number of advantages in this regard, which suggest that their impact might be greater than that of curricular EO clinics. Supervision and training can be limited to ensuring that clients gain acceptable levels of service rather than the personal development of students, thus allowing 
for much higher staff-student ratios and hence more students serving more clients. In addition, they can remain in extra-curricular clinics for the duration of their studies. While this will expand the breadth of their experiential learning, its quality can be enhanced by classes devoted to exploring the ethics and justice of law, legal practice and the legal system and providing students with opportunities for the sort of guided reflection which is essential to make the most of experiential leaning in general (Brayne et al, 1998) and community service in particular (Wizner \& Aiken, 2004; Schmedemann, 2009; Adcock, 2013; Morin \& Waysdorf, 2013). As an example of such a 'hybrid' clinic (Nicolson, 2006), for a budget of around $£ 80,000$ a year, the USLC has over 200 student volunteers - approximately a third of all law school students - who remain members for up to five years in which they represent around ten clients, as well as sitting in on evening advice sessions and engaging in other forms of community service such as public legal education programmes in schools and prisons, supporting gender violence survivors, law reform work and the investigation of miscarriages of justice.

Compared to EO clinics, SJO clinics thus have economies of scale which allow ATJ to be better served both directly by redressing more unmet legal need and indirectly by ensuring students a more extended exposure to the sort of clinical experience which may develop or at least sustain a commitment to enhancing ATJ on graduation. Arguably, they have other advantages in regard to this latter goal. One is that prioritising student education over community service risks undermining this goal by implicitly conveying to students that their interests - now educational but later commercial - trump those of clients and the community. Moreover, choosing cases in terms of their educational value rather than client needs (as some clinics apparently do: Nicolson 2006) reduces the chances of learning lessons about the dire state of ATJ and the satisfaction to be gained in helping those affected. 
Secondly, three features of extra-curricular clinics enhance their potential to successfully transmit their more altruistic message and to act as an alternative model to neoliberal legal practice. One is that long-standing involvement in a distinct organisation, with perhaps a constitution, elections or an appointment process for committee positions, creates condition conducive to a much stronger and cohesive ethos which can be transmitted through an AGM and committee meetings, as well as formal and informal social events, and other forms of informal socialisation which arise when people are involved in working close with and forming friendships with like-minded colleagues (cf Jackson et al, 1995). Secondly because students often help run such clinics, they are more likely to feel a sense of 'psychological ownership' in 'their clinic' and its goals. According to empirical research, this tends to lead to them going the extra mile in fulfilling their responsibilities (Pierce et al, 2001; O' Driscoll et al, 2006), but it may also reveal to students a more effective and civilized alternative to the new managerialism of legal practice. Thirdly, students who give up time to help run the clinic as well as helping clients act as altruistic role models.

However, notwithstanding the USLC'ss relatively cost-effective model, resource limitations and the commitment to select students who are primarily motivated by social justice means that around half of the 120 or so students who apply each year have to be turned away.:- Consequently, their desire for experiential learning is met by arranging opportunities for externships in legal advice agencies and participation in the USLC's public legal education programmes. And, in order to maximise the potential for these experiences to raise awareness of ATJ problems and inculcate a commitment to redress them, these students are also offered classes which, in addition to developing relevant legal and transferable skills, encourage them to reflect on their experiences in the light of reading and class discussion on ATJ and legal ethics. 
Admittedly, such potential is already rather limited given that many of these students have already been judged to lack the necessary altruism for USLC membership and none will be subjected to the socialisation effects of a cohesive organisation with a strong social justice ethos, whereas those engaging in public legal education will not experience the potentially empathy inducting experience of assisting those who would otherwise lack legal assistance. However, for law schools which cannot afford an EO or a curricular SJO clinic, or who do not have staff willing to support extra-curricular clinics, other forms of active learning will certainly go some way to accommodate students who are motivated to study law in order to serve justice. It will also enable the exploitation of less altruistic students' thirst for greater engagement with legal practice for the purposes of developing in at least some of them a greater sensitivity to ATJ problems and a commitment to their redress.

The pejorative connotations of 'exploitation' might however raise ethical eyebrows. Utilitarians will respond that any harm to students is justified by the overriding benefit to the community. Certainly, it is arguable that any such exploitation is less than that involved in EO clinic students 'practising on the poor' (Thornton, 2010, p. 83), rather than for the poor. But even in terms of Kantian ethics, students involved in clinical programmes which prioritise social justice are not treated merely as a means to such ends. Even if not formally trained to ensure a quality service to clients, they cannot but acquire enhanced employability, skills and knowledge from case and public legal education work, as well management, teamworking and other valuable 'transferable skills' in helping to run extra-curricular clinics. Moreover, as long as law schools make clear that students must prioritise client and community needs over their own educational interests and that clinical classes include a focus on ethics and justice, prospective students are always free not to participate or to apply to universities with EO clinics. 
Similar arguments suggest that the increasing desire by universities to enhance graduate employability is not being exploited when they fund clinical programmes which openly prioritise social justice. More fundamentally, however, it might be argued that universities should never prioritise community service over student education (see eg De Klerk, 2007, 98). In response, it can be noted that it has recognised since at least the nineteenth century when Humbolt developed his vision of universities contributing to the common weal through research as well as teaching. Today this extends to 'knowledge exchange/ transfer' whereby universities share learning, ideas and experience with the community (Thornton, 2010, ch. 5). Admittedly many might see this more in terms of marketing the products of research rather than public service, but Thornton herself notes that neo-liberalism has encouraged stronger university links with the community (Thornton 2010, p. 206). Indeed, the University of Strathclyde showcases the USLC as fulfilling its founding mission as a 'place of useful learning' notwithstanding its strong entrepreneurial focus (Clarke, 1998).

But even as regards universities' educational mission, SJO clinical programmes arguably make no less a contribution than EO programmes. Thus, their goal of instilling in students a commitment to ATJ is more closely aligned to that of liberal legal education of producing good citizens. Moreover, while EO clinics clearly have the advantage as regards developing vocational skills and knowledge, their more indirect acquisition by far more students in SJO clinics might well lead to greater overall educational enhancement.

More fundamentally, it can be asked whether those who pay for legal education are likely to object to clinics prioritising community service over education. Fee-paying students can always apply to universities with EO clinics, but may in fact prefer to opt for the longerlasting and more varied practical experience of extra-curricular SJO clinics, especially if access to intensive clinical classes is rationed. And to the extent that legal education is publicly funded, it seem unlikely that many taxpayers will baulk at law schools seeking to 
redress the fact that many of their graduates currently do not repay the privilege of a publicly funded legal education by reducing unmet legal need.

\section{Conclusion: towards an activist legal education}

While this article was primarily directed at exploring the role of ATJ in legal education, less directly it sketches a more general vision of legal education which adds to the growing consensus that the distinction between the liberal and vocational approaches to legal education is artificial and overly rigid (eg Hepple, 1996, Johnstone 1999; Boon \& Webb 2010). Instead, this vision - like that of Goldsmith (1999, 2002; Goldsmith \& Bamford, 2010) - sees student involvement in work environments as an effective- if not the most effective means of pursing the goals of a critical legal education through encouraging students to reflect on how law actually operates, its justice as well as access to justice and the ethical implications for practitioners. Such an education combines the focus on theory, context, justice and ethics which characterises a liberal legal education with the engagement with legal practice which characterises a vocational legal education in a way that is aimed at producing law graduates who see justice as part of their professional calling (Nicolson 2013).

While as regards the teaching of law, ethics and justice, this approach can be better described as critical rather than liberal, the term 'activist' better captures its overall aims and methods. Thus, it seeks to foster activists for justice, whether social justice more generally especially as regards those who do not enter legal practice, or substantive legal justice and access to justice more specifically if they do, and pursues these goals through providing opportunities for active learning in the context of legal practice.

The theoretical focus on critique and context should appeal those who share Thornton's vision of a socially liberal legal education, whereas the practical focus should 
appeal to students and universities who demand greater vocationalism and to high street and legal aid practitioners who want graduates with the sort of skills, knowledge and experience developed in law clinics and externships and to compete for the best graduates with the more powerful large law firms. The latter are likely to be ambivalent about an education which seeks to produce graduates who are more practice-ready, but less ready to practice for the benefit of those with the deepest pockets rather than in most need or, as Luban (1988, p.83) for 'the person-in-no-trouble, but-who troubles- others' rather than the 'person-in-trouble'. And although Bradney (2003) wants to resist the profession's demands for graduates ready to make money for their employers, the unashamed espousal of a particular view of legal practice and particular set of values rather than another (altruism rather than materialism) in an activist legal education seems also to conflict with his idea of an education exposing students to competing views but not seeking to privilege some over others. But just as market control distorts economic markets, I would argue that the dominance of the large law firms in the recruitment market justifies seeking to ensure something like a level playing field as regards competing professional visions. Furthermore, while engaging more with legal practice might, as the opponents of vocationalism argue, be unfair to the many law graduates who do not enter legal practice (at least if one thinks that law schools can teach law sufficiently accurately, critically or ethically without engaging with practice), not doing so is unfair to those who do go into practice, if not also to the many more who hope to do so, and certainly to those who suffer from problems of access to justice.

At the same time, despite believing strongly that law schools should pursue an activist agenda, there is no reason why its content should replicate that outlined in this article. There are many other issues (human rights, gender, race and class, for example), which could become the focus of attention, many other forms of experiential learning (problem-based learning or simulated practice scenarios, for example) which can be used, and myriad ways 
law schools can combine these two activist dimensions depending on particular interests, pedagogical beliefs and political commitments. Nevertheless, the vision sketched in this article should appeal to those who are convinced that students and academic who directly benefit from legal education have a moral obligation to promote justice, while simultaneously responding to many of the directly opposed pressures which stem from the forces of neoliberalism.

\section{References}

Adcock, C. (2013) Beyond Externships and clinics: integrating access to justice education into the curriculum, Journal of Legal Education, 62(4), pp. 566-575

Baldwin, J. \& McConville, M. (1977) Negotiated Justice: Pressures to Plead Guilty (London, Martin Robertson).

Bloch, F. (1982) The andragogical basis of clinical legal education, Vanderbilt Law Review, 35(2), pp. 321-54.

Boas, T. C. \& Gans-Morse, J. (2009) Neoliberalism: from new liberal philosophy to antiliberal slogan, Studies in Comparative International Development, 44 (2): pp. 137-161.

Boon, A. (1998) History is past politics: a critique of the legal skills movement in England and Wales, Journal of Law and Society, 25(1), pp. 151-69.

Boon, A. and Webb, J. (2010) The legal profession as stakeholders in the academy in England and Wales, in: F. Cownie (Ed) Stakeholders in the Law School (Oxford, Hart Publishing), pp. 65-96. 
Boon, A. and Whyte, A. (2010) Will there be blood? students as stakeholder in the legal academy, in: F. Cownie (Ed) Stakeholders in the Law School (Oxford, Hart Publishing), pp. 185-224

Bradney, A. (2003) Conversations, Choices and Chances: The Liberal Law School in the Twenty-first Century (Oxford, Hart Publishing)

Brayne, H., Duncan, N. \&. Grimes, R. (1998) Clinical Legal Education: Active Learning in Your Law School (Blackstone Press Ltd, London).

Brownsword, R. (1999) Law schools for lawyer, citizens, and people in: F. Cownie (Ed), The Law School : Global Issues, Local Questions (Aldershot, Ashgate/Dartmouth)

Clark, B. (1998) Creating Entrepreneurial Universities: Organizational Pathways Transformation (Oxford, IAU Press).

Clarke, J. (2004) Dissolving the public realm? the logics and limits of neo-liberalism, Journal of Social Policy, 33(1), pp.27-48.

Davis, G., Cretney, S. \& Collins, J. (1994) Simple Quarrels: Negotiations and Adjudication in Divorce (Oxford, Clarendon Press).

Willem De Klerk, Unity in Diversity: Reflections on Clinical Legal Education in South Africa, 12 Int'l J. Clinical Legal Educ. 95, 99-101 (2007

Francis, A. (2005) The business context: legal ethics, the marketplace and the fragmentation of legal professionalism, International Journal of the Legal Profession, 12(2), 173-200.

Genn, H. (1987) Hard Bargaining: Out of Court Settlement in Personal Injury Actions (Oxford, Clarendon Press).

Genn, H. (1999) Paths to Justice: What People Think and Do about Going to Law (Oxford, Hart Publishing)

Genn, H. and Paterson, A (2001), Paths to Justice Scotland: What People Think and Do about Going to Law In Scotland (Oxford, Hart Publishing) 
Goldsmith, A, (2002) Why should law matter - toward a clinical model of legal education, UNSW Law Journal, 25(1), pp. 721-747.

Goldsmith, A. and Bamford, D (2010), The value of practice in legal education, in: F. Cownie (ed) Stakeholders in the Law School (Oxford, Hart Publishing), pp. 157-184.

Granfield, R. \& Veliz, P (2009), Good lawyering and lawyering for the good: lawyers' reflections on mandatory pro bono in law school, in: R Granfield and L Mather (Eds), Private Lawyers \& the Public Interest: The Evolving Role of Pro Bono in the Legal Profession (Oxford, Oxford University Press)

Guth, J and Ashford C, (2014), The legal education and training review: regulating sociolegal and liberal legal education? The Law Teacher, 48(1), pp. 5-19.

Harris, P and Beinart, S (2004), A survey of law schools in the United Kingdom, 2004, The Law Teacher, 39(3), 299-366.

Hepple, B. (1996) The renewal of the liberal law degree, Cambridge Law Journal, 55(3), pp. $470-487$.

Hoffman, Empathy and Moral Development: Implications for Caring and Justice Jackson, E.F, Bachmeier, M.D., Wood, J.R. and Craft (1995) Volunteering and charitable giving: do religious and associational ties promote helping behaviour', Non-proft and Voluntary Sector Quarterly, 24, pp. 59-79

Johnstone, G. (1999), Liberal ideals and vocational aims in university legal education, Web Journal of Current Legal Issues, issue 3, available at http://www.bailii.org/uk/other/journals/WebJCLI/1999/issue3/johnstone3.html

Law Society and the General Council of the Bar (1995) Joint Statement on the Academic Stage of Training, available at http://www.sra.org.uk/students/academic-stage-jointstatement-bsb-law-society.page. 
Law Society of Scotland (2010), Foundation Programme (Scottish Exempting Degree):

Accreditation Guidelines for Applicants, available at

http://www.lawscot.org.uk/media/561666/foundation\%20programme\%20guidelines.pd

f

Lee, R.G. (1992) From profession to business, the rise and rise of the city law firm, Journal

of Law and Society, 19(1), pp. 31-48.

Luban, D. (1988) Lawyers and Justice: An Ethical Study (Princeton, N.J., Princeton University Press)

McConville, M., Hodges, J. Bridges, L. and Pavlovic, A. (1994) Standing Accused: The Organisation and Practices of Criminal Defence Lawyers in Britain (Oxford, Clarendon Press).

Morin, L.A, \& Waysdorf, S.L. (2013) Teaching the reflective approach within the servicelearning model, Journal of Legal Education, 62(4), pp. 600-11.

Nicolson, D. (2006) Legal education or community service? the extra-curricular student law clinic, Web Journal of Current Legal Issues, issue 3, available at http://www.bailii.org/uk/other/journals/WebJCLI/2006/issue3/nicolson3.html

Nicolson, D. (2008), Education, education, education: legal, moral and clinical. The Law Teacher 42(2), pp. 145-173.

Nicolson, D. (2010), Learning in justice: ethical education in an extra-curricular law clinic, in M. Robertson, L. Corbin, K. Tranter, \& F. Bartlett(eds), The Ethics Project in Legal
Education, (London: Routledge), pp. 171-90

Nicolson, D. (2012) Access to Justice and the Legal Profession, SCOLAG, Issue 416, pp.13336.

Nicolson, D. (2013), Calling, character and clinical legal education: a cradle to grave approach to inculcating a love for justice, Legal Ethics, 16(1), pp. 36-56. 
Nicolson, D. (2015), "Our roots began in Africa": A multi-variate analysis of aligning university law clinics with social justice ends, New York Law School Law Review (forthcoming)

Nicolson, D. and Webb, J. (1999) Professional Legal Ethics: Critical Interrogations (Oxford: Oxford University Press)

O Driscoll, M.P., Pierce, J.L. and Coghlan, A-M. (2006) The psychology of ownership: work environment structure, organizational commitment. and citizenship behaviours, Group and Organization Management, 31(3), pp. 388-416

Paterson, A. (2011) Lawyers and the Public Good: Democracy in Action (Cambridge: Cambridge University Press).

Partington, M. (1988) Academic lawyers and 'legal practice' in Britain: a preliminary appraisal, Journal of Law and Society, 15(4), pp. 374-391.

Pierce, J.L., Kostovsky, T. \& Dirks, K.T. (2001) Towards a theory of psychological ownership in organisations, Academy of Management Review 26(2), pp. 298-310

Rawls, J. (1989) A Theory of Justice (Cambridge, Mass, Harvard University Press, revised edn)

Rest, J, (1994) The four components of acting morally, in: J. Rest and D. Narvaez (eds), Moral Development in the Professions: Psychology and Applied Ethics (Hillsdale, N.J.: Lawrence Erlbaum Associates)

Rhode, D.L. (2004), Access to Justice (Oxford, Oxford University Press).

Rhode, D. (2013), Access to justice: an agenda for legal education and research, Journal of Legal Education, 62(4), pp. 531-550

Sandefur S. R. and Selbin, L. (2009) The clinic effect. Clinical Law Review, 16(1), pp. 57107. 
Sarat, A. and Scheingold, S.A. (2001) Cause Lawyering and The State in a Global Era (New York, Oxford University Press).

Sommerlad, H (1995) Managerialism and the legal profession: a new professional paradigm, International Journal of the Legal Profession, 2(2-3), pp. 159-185.

Sommerlad, H (2008), Reflections on the reconfiguration of access to justice, International Journal of the Legal Profession, 15(3), pp. 179-93.

Thornton, M. (2010) Privatising the Public University: The Case of Law (London, Routledge)

Thornton, M. (2012) The new knowledge economy and the transformation of the law discipline, International Journal of the Legal Profession, 19(2-3), pp. 265-281.

Webb J. (1999) Post-fordism and the reformation of Liberal Legal Education, in: F. Cownie, (ed) The law School : Global Issues, Local Questions (Aldershot, Ashgate/Dartmouth). Webb, J, Ching, J., Maharg, P. \& Sherr, A. , (2013), Setting Standards: The Future of Legal Services Education and Training Regulation in England and Wales (London, Legal Education and Training Review), available at http://letr.org.uk/the-report/index.htm Wizner Steven \& Aiken, Jane Teaching and Doing: The Role of Law School Clinics in Enhancing Access to Justice, 73 Fordham L. Rev. 997, 1005 (2004).

\footnotetext{
${ }^{\mathrm{i}}$ I would like to thank Hilary Sommerlad for initial suggestions as to content and reading, James Campbell for his superb research assistance, and an anonymous reviewer for helpful comments.

ii See Webb et al, 2013 and the special edition of The Law Teacher $(2014,48(1))$ devoted to debating its implications.

iii For a more detailed analysis of the diaries and the methodology used, see Nicolson, 2010.
} 
iv Indeed, it is arguable that such financial contributions via a levy on practicising certificates should be the default position for all lawyers unless they can establish some role in enhancing ATJ (Nicolson, 2012).

${ }^{v}$ Prospective members must persuade an interview panel that the student is more interested in furthering social justice than their own needs - though as Isla and Calum show, this process is not fool-proof.

vi The following comparison is confined to in-house clinics given that the US pro bono programmes researched are so wide-ranging and not confined to serving those facing ATJ obstacles (less than $50 \%$ in Granfield, 2007). 